\section{O PODER FEMININO NA "ANDRÔMACA" DE EURÍPIDES}

Female Power in Euripides' "Andromache"
Fábio de Souza

Lessa

(iD fslessa@uol.com.br

Universidade Federal do

Rio de Janeiro,

Rio de Janeiro, RJ, Brasil

\section{Resumo}

Encenada durante a guerra do Peloponeso, a tragédia Andrômaca de Eurípides permite a discussão acerca das relações de poder estabelecidas entre esposa legítima e concubina, mulheres e homens e também espartanas e troianas. Neste artigo, propomos estudar essas relações de poder feminino na Atenas clássica. A disputa de poder entre Hermíone e Andrômaca tem como base o casamento e a condição de esposa legítima, a maternidade e os espaços de atuação das mulheres gregas. Há ainda um embate de poder entre a cultura dos gregos e a dos não gregos, nos remetendo às discussões acerca do conceito de etnicidade.

Palavras-chave: Gênero, etnicidade, Atenas Clássica, teatro grego.

\section{Abstract}

Staged during the Peloponnesian War, Euripides' tragedy "Andromache" fosters debate on power relations established between legitimate wife and concubine, women and men, and also Spartan and Trojan women. The purpose of this article is to study these relations of feminine power in classical Athens. The power struggle between Hermíone and Andromache is based on marriage and the status of legitimate wife, motherhood and the areas of activity of Greek women. There is also a conflict of power between the culture of the Greeks and that of the non-Greeks, referring to discussions about the concept of ethnicity.

Keywords: Gender, ethnicity, Classical Athens, Greek theater. 
Que gosto tenho então em viver? Para onde devo olhar? Para as presentes ou passadas desgraças?

(EURIPIDES. Andrômaca, vv. 404-06)

presentada durante a Guerra do Peloponeso (431-404 a.C.), possivelmente na primeira metade da década de 430-20 a.C., a Andrômaca ${ }^{1}$ de Eurípides aborda dois motivos do mito da guerra de Troia de forma agregada: um sobre a viúva de Heitor (Andrômaca), sua vida como exilada na Grécia e concubina do filho de Aquiles, Neoptólemo; outro sobre o casamento de Neoptólemo com Hermíone e seu assassinato por Orestes, a quem Hermíone tinha sido originalmente prometida em casamento (CHONG-GOSSARD, 2015, p. 143). Na realidade, Andrômaca coloca no centro de sua ação um conflito familiar enraizado na própria instituição matrimonial.

A epígrafe que inicia este texto, uma fala de Andrômaca na iminência da morte de seu filho com Neoptólemo, faz referência às desgraças vivenciadas pela personagem no passado frente à destruição de Troia, e àquelas do presente, notadamente a morte de seu filho e a sua condição de cativa de guerra. Esse jogo entre passado e presente é certamente uma metáfora para o poeta fazer com que os atenienses ponderassem sobre duas guerras: a de Troia, no imaginário homérico, e a do Peloponeso, vivenciada no momento pelos helenos. Até mesmo porque a "sua própria atividade literária [...] foi, como veremos, fortemente influenciada pela laceração interna do Estado ateniense durante a guerra do Peloponeso" (DI BENEDETTO, 1971, p. ix).

Tucídides, com tons realistas de sua narrativa historiográfica, descreve as atrocidades vivenciadas devido à guerra: morte dos homens capturados em idade militar e redução de mulheres e crianças à escravidão (cf. TUCIDIDES. V, 116). Logo, enquanto os heróis, mortos em combates, serão recompensados pela memória coletiva; mulheres e crianças, diante da morte de seus pais e esposos, ficam relegados à escravidão e à morte (SILVA, 2013, p. 361). A própria personagem Andrômaca (vv. 396-7) admite que, em tempos de guerra, os filhos não são bem-vindos, porque somente contribuem para aumentar o sofrimento que afeta às suas mães.

É nesse cenário que Eurípides nos propicia uma reflexão sobre as relações de poder estabelecidas entre mulheres - Andrômaca versus Hermíone -, entre homens - Peleu versus Menelau -, entre mulheres e homens - Andrômaca versus Menelau - e entre gregos e não gregos / gregos e bárbaros. Todas essas relações de poder nos remetem a dois conceitos teóricos norteadores deste texto, a saber: gênero e etnicidade, ambos discursos de poder construídos socioculturalmente.

No plano ideológico/simbólico, a sociedade helênica parece ter assumido prioritariamente uma polaridade antagônica e desigual entre homens e mulheres (GURINA, 2008, p. 11). Polaridade essa que também pode ser estendida para as relações entre gregos e não gregos. Podemos resgatar Jean-Pierre Vernant (1999, p. 9) quando afirma que a tragédia "não poderia refletir uma realidade que, de alguma forma, Ihe fosse estranha". 
Lin Foxhall (2013, p. 1) afirma que a questão do gênero² é fundamental para a nossa compreensão da Antiguidade, como o é para o mundo que nos rodeia hoje. O passado e o presente estão engajados em uma conversa complexa neste domínio. A helenista ainda ressalta que a Antiguidade clássica tem sido evocada para justificar construções específicas do gênero nos últimos tempos, e nossa redescoberta moderna e pós-moderna do gênero no passado tem sido estimulada, em grande parte, pelas mudanças revolucionárias ocorridas em nossa sociedade a partir de fins do século XX. O que com certeza permitiu, conforme afirma Violaine Sebillotte Cuchet (2018, p. 143), que as pesquisas realizadas a partir dos anos 2000 sublinhassem ao mesmo tempo a capacidade de ação das mulheres na esfera pública e a existência de uma definição feminina no vocabulário da cidadania.

Podemos considerar que a categoria gênero procura evidenciar que a construção do feminino e do masculino aparece interligada3; isto porque cada um dos gêneros é definido, a partir da organização cultural, em função do outro. Ao refletir sobre a dimensão cultural presente na categoria de análise gênero, Violaine S. Cuchet (2014, p. 60) afirma que este “... é às vezes empregado para designar o fato de que características físicas, comportamentais ou culturais, recebem a conotação de feminino e masculino". Dessa forma, no mundo grego, fraqueza e moleza, mais consentâneas com o ambiente doméstico, são associadas ao feminino, enquanto valentia e coragem, exigidas por uma atuação mais coletiva e exterior, ao masculino.

Gênero é um dos objetos mais difíceis do estudo histórico, uma vez que é quase impossível de nos separarmos dele e, ao mesmo tempo, é ainda um dos aspectos mais fascinantes do mundo antigo - e do passado em geral -, que muitas vezes se apresenta como particularmente acessível porque se constitui em uma parte essencial de todas as nossas relações socais, bem como de nossas identidades pessoais. Lin Foxhall (2013, p. 2) atenta para o fato de que a presença do elemento biológico no gênero - "masculino", "feminino" e seus corpos físicos - significa que há algo relativamente fixo e compartilhado sobre o gênero ao longo da história humana.

Concordamos com L. Feitosa e M. Rago (2008, p. 108) quando afirmam que as discussões propiciadas pela categoria gênero atuaram efetivamente no processo de autonomização do sexo, enfatizando teoricamente que as diferenças sexuais resultam de construções culturais, sociais e históricas, se distanciando das explicações essencialistas de cunho puramente biológico e possibilitando, assim defendemos, a desconstrução da divisão dos sexos que se constituía no cerne do pensamento político helênico. O feminino e o masculino se caracterizam pela pluralidade, cabendo aos especialistas reconhecer diferenças dentro da diferença, ressaltando que mulher e homem constituem grupos heterogêneos; isto é, não são simples aglomerados (MATOS, 2006, p. 14).

Joan Scott (1995, p. 86; 1994, p. 20) já havia apontado para essas questões ao constatar que "o gênero é um elemento constitutivo das relações sociais baseadas nas diferenças percebidas entre os sexos" e ainda que "o gênero é uma forma primária de dar significado às relações de poder". Assim sendo, gênero adquire a conotação de uma organização social da diferença sexual, baseada nos saberes, nas instituições, 
no poder e práticas produzidas pelas culturas sobre as relações entre homens e mulheres/masculino e feminino.

Também construído historicamente, o conceito de etnicidade é fundamental para entendermos a tensão que se estabelece entre Andrômaca - uma cativa trazida de Troia como espólio de guerra - e Hermíone - espartana, filha de Menelau e Helena. No que se refere à relação entre tragédias e alteridades, Vidal-Naquet (1997, p. 119) afirma que cada tragédia ateniense apresenta uma reflexão sobre o estrangeiro, sobre o Outro. Não seria errôneo afirmar que a dinâmica essencial do teatro grego consiste na representação do Outro, da alteridade, nas suas diversas nuances: gregos e não gregos, masculino e feminino, livres e escravos, esposas e concubinas... Interessante é observarmos que o drama euridipiano oferece, assim como ressalta Lidia Gambon (2009, p. 17), um amplo leque de caracteres que cobre todos os estatutos, desde deuses e reis a cidade/cidadãos e escravos; as origens mais variadas, gregos e não gregos, atenienses e não atenienses; todos os grupos sociais, desde idosos a crianças.

As últimas décadas têm se dedicado também à reflexão acerca das discussões sobre etnicidade. Philippe Poutignat e Jocelyne Streiff-Fenart (1998, p. 86) chamam a atenção para o fato de que para alguns autores "a etnicidade refere-se a um conjunto de atributos ou de traços tais como a língua ${ }^{4}$, a religião, os costumes, o que a aproxima da noção de cultura, ou à ascendência comum presumida dos membros, o que a torna próxima da noção de raça". Outros estudiosos a definem em termos de comportamentos, de representações ou de sentimentos associados à pertença, ou ainda em termos de um sistema cultural, sendo a cultura entendida como "simultaneamente um aspecto da interação concreta e o contexto de significação desta mesma interação...” (POUTIGNAT; STREIFF-FENART, 1998, p. 86, 109-10).

O conceito deriva do termo grego éthnos. Há certa unidade em suas definições. A. Bailly (2000, p. 581) o traduz como "raça, povo, nação, tribo". Liddell \& Scott (1992, p. 480) acrescentam às traduções anteriores mais uma noção, a de "número de pessoas vivendo juntas". Já Pierre Chantraine (1983, p. 301) opta por traduzi-lo como "grupo mais ou menos permanente de indivíduos, pessoa estrangeira, bárbara” ou ainda "estrangeiro ao gênos, à família". A literatura grega concede à dicotomia entre helenos e bárbaros um destaque relevante, em especial a dramática. Edith Hall (2004, p. 3-4) sublinha que o gênero trágico no século $V$ a.C. demarcava os gregos do resto do mundo através da polaridade gregos versus bárbaros. Neste sentido, Eurípides é um testemunho singular, pois “... a sua noção de 'estrangeiro' é mais geral, representada por um conjunto de elementos estereotipados, que sobretudo produzem com o modelo grego pontos de divergência e conflito". Importante é destacar que, com o tempo e com um conhecimento (SILVA, 2005, p. 18) mais próximo do estrangeiro, o teatro começa a tender para a redução da dicotomia grego/bárbaro e a considerar que o que de fato distingue os homens não é propriamente a cultura, mas a circunstância em que, como seres humanos, são chamados a agir. Porque todos, gregos e bárbaros, diante da crise agem da mesma maneira.

Nos versos iniciais da tragédia (vv. 1-4), Eurípides já apresenta a sua protagonista - Andrômaca - como não grega. O seu passado está vinculado com Troia, pois foi 
esposa de Heitor e mãe dos seus filhos. Na llíada (6. 429-30) observamos uma clara dependência de Andrômaca em relação a Heitor: "Heitor, tu para mim és pai e excelsa mãe; és irmão l e és para mim o vigoroso companheiro do meu leito". ${ }^{5}$ A sua absoluta dependência pode ser explicada por dois fatores interligados: primeiro, porque a morte de Heitor e a previsível derrota de Troia serão, para Andrômaca, fonte de sofrimento, conforme vemos na narrativa de Eurípides; segundo, porque o mundo da personagem tem um único centro e esse é Heitor, haja vista a citação acima (DESERTO, 2012, p. 94). Importa lembrar que, na llíada, a cidade de proveniência de Andrômaca, Tebas, foi antes arrasada por Aquiles e os seus parentes, mortos. O mesmo Aquiles será responsável pela morte de Heitor. É, portanto extremamente penoso que Andrômaca venha a caber em sorte ao filho de Aquiles, o seu pior inimigo.

A fidelidade ao passado troiano e à memória de Heitor sobressai na construção da personagem euridipiana e se justifica pela sua condição de nobre e de esposa legítima do filho de Príamo. Ela própria destaca que "digna de inveja, no tempo passado, era Andrômaca" (v. 5).

\section{O gênero feminino em confronto: Andrômaca versus Hermíone}

Duas personagens femininas fortes em conflito - Andrômaca e Hermíone constituem o fio condutor da Andrômaca de Eurípides. A força de Andrômaca se encontra inclusive na etimologia do seu nome: ele reúne o homem - anér - e o combate - máche (VIDAL-NAQUET, 2002, p. 79), significando "aquela que luta/guerreia com homens". ${ }^{6}$ Assim, ela se distanciaria da noção idealizada de esposa, pautada na ideia de fraqueza e debilidade. Mas, apesar dessa constatação, no mundo grego "às mulheres não era permitido tomar a palavra na assembleia, votar, ser magistrada ou participar do exercício cívico" (CUCHET, 2018, p. 154). Apesar dessas limitações formais, defendemos que as esposas atenienses agiam social e civicamente. Entendemos cívico como uma esfera que excede à formalidade política.

Andrômaca e Hermíone possuem características marcantes e opostas. O quadro busca sistematizar tais oposições:

\begin{tabular}{c|c}
\hline Andrômoca & Hermíone \\
\hline Troiana (vv. 1-4) & Espartana (vv. 29-30) \\
\hline $\begin{array}{c}\text { Cativa de guerra (vv. 12, 96-102, 110-11, 136-40, } \\
\text { 155-60, 185-87, 399-407, 582, 869-74) }\end{array}$ & Grega (vv. 29-30, 243) \\
\hline $\begin{array}{c}\text { Trazida para coabitar com Neoptólemo - } \\
\text { Concubina (vv. 12-15) }\end{array}$ & Espos-74) \\
\hline Mãe (vv. 26, 68, 70, 74-5, 310, 339/40...) & Estéril (vv. 29-30, 155-60, 355-56, 710, 711-12) \\
\hline Impedida de falar (vv. 185-87) & Pode falar livremente (vv. 152-3) \\
\hline Mais velha & Jovem (v. 238) \\
\hline- & Mulher malvada / respira arrogância (vv. 189-91) \\
\hline Fraca7 (v. 755) $^{7}$ & - \\
\hline
\end{tabular}

Tabela 1. Confronto Andrômoca versus Hermíone 
Podemos dizer que Andrômaca é uma obra que gira em torno de uniões malfadadas que conduzem à ruína de uma casa (RODRÍGUEZ CIDRE, 2010, p. 60). O início da obra (vv.1-56) já apresenta esse quadro: Andrômaca se encontra no altar da deusa Tétis suplicando pela vida do filho e pela sua própria, pois Hermíone decidiu matá-los para salvaguardar a sua condição de esposa legítima. A diferença de status entre as personagens pode ser entendida como o elemento estruturante da peça e não propriamente o contexto da guerra em si, mesmo que tenha sido a guerra de toda a questão envolvendo as duas personagens. Talvez o cerne da questão esteja na discussão acerca do estatuto da concubina que gravita entre o da esposa legítima e o da hetaira (cortesã). De fato, o conflito se encontra entre dois leitos de status diferentes. No prólogo, Andrômaca evidencia essa diferença: "Mas desde que o meu senhor desposou a lacônia Hermíone, I desprezando o meu leito servil, sou por ela perseguida com insultos cruéis" (vv. 29-31). ${ }^{8}$

Para um cidadão ateniense manter uma esposa legítima e uma concubina, com o conhecimento da própria esposa, era algo comum. Porém, a tensão se dá pela coabitação no oîkos do casal. Certamente é uma afronta para uma esposa conviver com outra mulher no seu espaço de administração e atuação. Orestes afirma na tragédia que "má coisa disseste: um homem possuir dois leitos" (v. 909).

A diferença de status entre as personagens é inquestionável na tragédia, porém o conceito grego para concubina, pallaké, se encontra ausente ${ }^{9}$, talvez porque o termo pallaké se refira a uma mulher livre que possa conceber filhos igualmente livres. Eva Keuls (1993, p. 268-69) menciona a ausência do concubinato escravo na documentação, mas assinala que a palavra grega pallaké não tem um significado legal preciso e pode se referir a mulheres que vivem em relações não legalizadas, quer tenham status de escrava, livre ou liberta. O importante é destacar que é comum nas tragédias as mulheres cativas de guerra compartilharem o leito com os seus senhores, podendo fazê-lo como concubina e/ou escrava. Em parte, isso dependerá de sua condição social prévia. No caso de Andrômaca, ela pertencia a um grupo social elevado em Troia, o que a transforma em concubina e não em uma simples escrava, em se tratando de sua nova situação social (RODRíGUEZ CIDRE, 2010, p. 54). A tragédia acaba reafirmando os riscos desta ausência de diferenciação de status entre esposa legítima e concubina, ao apresentar uma cativa convivendo sob o mesmo teto de uma esposa e, dessa forma, anular a distância espacial que demarca a separação entre ambas (GAMBOM, 2009, p. 174).

Esse conflito se agrava com a oposição maternidade versus esterilidade. É sabido que a principal função social feminina é a concepção de filhos, em especial do sexo masculino, e que o casamento visa a continuidade do grupo doméstico e da comunidade política. Não nos esqueçamos de que "a capacidade de gerar crianças cidadãs é o direito político fundamental reservado aos cidadãos/cidadãs” (CUCHET, 2018, p. 148). Reforçamos tal aspecto porque o conflito entre as duas personagens se encontra essencialmente na esfera da maternidade, algo interditado a Hermíone. Apesar de Andrômaca ter mais idade do que ela (v. 238), o seu potencial fértil é indiscutível. É salutar destacar que neste aspecto de faixa etária observamos no universo trágico 
um distanciamento do comumente encontrado na sociedade ateniense. O comum é o casamento de um homem mais maduro - em torno dos 30 anos ou mais - com uma mulher bem mais jovem, por volta dos 12/14 anos de idade. No caso da relação Andrômaca-Neoptólemo, essa situação se inverte: ela é bem mais idosa do que o marido $^{10}$. Talvez essa relação apresentada por Eurípides fosse possível em se tratando de uma concubina e não de uma esposa legítima. Até mesmo porque no casamento se busca a concepção de filhos, o que teoricamente uma jovem esposa estaria mais apta a realizar. Teoricamente porque neste caso também Eurípides, na relação Andrômaca-Hermíone, subverte a "normalidade".

Diferente da filha de Helena, que é na peça estéril, Andrômaca foi mãe no seu casamento com Heitor e viu o seu filho Astíanax ser lançado pelos gregos do cimo das elevadas torres de Troia (vv. 10-11); agora é novamente mãe, do filho de Neoptólemo (vv. 26, 68, 70, 74-5, 310, 339-40...). Pierre Vidal-Naquet (2002, p. 79) salienta este aspecto para a Andrômaca homérica: "Dessa multidão de troianas, Andrômaca é, com exceção de Hécuba, a única a ser identificada pelo poeta da llíada como esposa e mãe”.

A esterilidade de Hermíone (vv. 29-30, 155-60, 710, 711-12) gera a sua tentativa de assassinar Andrômaca e o filho. A acusação é o uso de drogas secretas pela cativa para gerar a sua esterilidade e para que pudesse expulsá-la do seu tálamo (vv. 33-35, 355-56). ${ }^{11}$ Tal atitude da espartana revela o seu conhecimento de que, sem filhos, o seu casamento se tornava inócuo. Vale reforçar que o casamento entre os gregos possuía implicações outras. Em dois momentos da tragédia observamos que as uniões matrimoniais resultavam de uma aliança (vv. 619-21) que não pressupunha a consulta às jovens, pois "dos meus esponsais meu pai cuidará, e não me pertence a mim [Hermíone] decidir” (vv. 988-89).

Como defesa, Andrômaca evoca a sua condição de escrava e questiona a responsabilidade de Neoptólemo sobre o fato, pois "partilhei, forçada - bía --, o leito com o meu senhor; e então queres matar-me a mim e não a ele, que é o culpado disto?" (vv. 390-92). Logo, a união de Andrômaca com Neoptólemo não atende aos quesitos de um acordo matrimonial. A Andrômaca de Eurípides se mantém fiel à memória de Heitor (vv. 36-38), aceitando essa nova relação com Neoptólemo essencialmente por necessidade. No contexto homérico, Heitor podia imaginar todo o desfecho da situação de sua esposa no pós-guerra e o seu sofrimento como cativa. O que sua imaginação não alcançou foi o fato de que depois de sua morte, Andrômaca contrairia um novo matrimônio e conceberia novos filhos (SCODEL, 1998, p. 139). A personagem também destaca a crueldade que caracteriza o gênero feminino quando se trata de rivais do leito conjugal (vv. 185-87). Mesmo que resultante de uma relação forçada, o contato sexual com o filho de Aquiles atua no sentido de representar parte do aceite por Andrômaca da sua escravidão (GAMBOM, 2009, p. 188).

Esta discussão alcança os filhos nascidos de uniões com concubinas. Há toda uma reflexão sobre o direito ou não à cidadania por parte dos filhos desse grupo feminino. Sarah Pomeroy (1999, p. 109), por exemplo, enfatiza que após as leis sobre cidadania de 451-50 a.C ${ }^{12}$, os filhos de concubinas não poderiam ser considerados cidadãos e tinham a sua capacidade legal para herdar questionada. Porém, como já 
dito, Andrômaca é encenada durante a guerra do Peloponeso e o contexto bélico impõe a necessidade de população masculina nos exércitos para a defesa da pólis nos exércitos. Certamente nesses contextos prevalecia, como critério para a cidadania, ser apenas filho de pai ateniense. Há ainda outro argumento que se costuma usar para esta decisão: a necessidade de uma cidade democrática, que garantia regalias aos seus cidadãos, definir e restringir a comunidade abrangida por essas prerrogativas. Paralela a essa questão, a pertinência de uma mulher na sociedade grega passava fundamentalmente pelo seu papel na reprodução (JUST, 1994, p. 47). Dessa forma, “a esposa deve demonstrar que serve como mulher sendo mãe” (RODRÍGUEZ CIDRE, 2010, p. 67).

O contexto de guerra com os espartanos se faz presente na Andrômaca e evidencia um arraigado sentimento antiespartano, não somente na composição do personagem Menelau, mas nas críticas às mulheres espartanas e à Helena, em especial. Além de ser vista como uma mulher malvada e que respira arrogância (vv. 189-91), a espartana Hermíone é caracterizada negativamente por Eurípides por ser filha de Helena. Peleu teria dito a Neoptólemo, seu neto: “... nem para a casa trazer a cria de uma mulher malvada [Helena]: transportam com elas as vergonhas maternas - metroi oneíde" (vv. 620-22). A Helena é atribuída toda a responsabilidade pela guerra de Troia:13

Para a excelsa Ílion Páris não esposa mas um flagelo levou, ao conduzir Helena para o tálamo. I Por sua causa, ó Troia, tomada a ferro e fogo, te destruiu o rápido Ares da Hélade de mil naus. Destruiu também a meu marido Heitor, desventurada de mim, a quem, em torno das muralhas, arrastou com seu carro o filho da marinha deusa Tétis (vv. 104-09).

A fuga de Helena para se unir com Páris (vv. 601-10) gera, na visão de Eurípides, a destruição de Troia - “... durante dez anos, andaram os jovens em armas. E nunca os tálamos teriam ficado desertos e órfãos de filhos os velhos" (vv. 305-07); "Muitas lágrimas me correram nas faces, por deixar em cinzas a cidade, casa e marido!" (vv. 111-14) - e todo o sofrimento de Andrômaca - viúva, escrava e na eminência de ver mais um de seus filhos assassinados. Interessante é pensarmos no sentido da guerra. Ela é, para as famílias, separação e ruptura. Os dois campos de batalha estão sujeitos a igual ruptura, porque a guerra é impiedosa e devora as pessoas (SILVA, 2013, p. 363-4).

A visão negativa de Helena se estende ao conjunto das espartanas. É resgatado o tipo de vida feminino lacedemônio, da prática dos exercícios físicos junto com os homens, frente ao ateniense, mais caracterizado pela reclusão no interior do oîkos:

E mesmo que o quisesse, nenhuma donzela espartana poderia ser casta. Elas na companhia dos rapazes, abandonam as casas de coxas nuas e peplos flutuantes, para estádios e palestras - o que para mim é intolerável - I frequentarem em comum (vv. 596-601). 
Tal crítica é recorrente na literatura ateniense, evidenciando a alteridade nos comportamentos femininos esperados pelas duas póleis. A ocupação de espaços tipicamente masculinos para os exercícios físicos - estádios e palestras -, a própria prática de uma educação mais física permitindo a aquisição de corpos mais rígidos, a nudez somada à convivência entre os homens gera um estranhamento para o público ateniense. E essa "licenciosidade" teve como consequência a própria guerra de Troia.

Hermíone apresenta uma visão negativa das mulheres, ao ponto de o Coro a censurar por isso: "Com excesso soltaste a língua contra o teu próprio sexo" (v. 954). A espartana ressalta que os maridos nunca devem permitir a frequência de outras mulheres em suas casas, pois "elas são mestres de males" e, em decorrência dessas visitas, os oîkoi adoecem. Continua a personagem afirmando que "visitas vindas de fora nada de bom trazem às mulheres, antes são causa de muitos males" (vv. 945$53)^{14}$. As mulheres são vistas nesta peça como "uma funesta calamidade" (vv. 352-55) e tendo a sua existência totalmente vinculada à presença do marido: “... mas, se lhe falta o marido, falta-lhe a vida" (vv. 373-75).

Fica evidente o afã de Eurípides em atacar Esparta e os espartanos, o que se torna compreensível no contexto bélico que opõe os atenienses aos lacedemônios. Além dessa feição, o contraste entre Andrômaca e Hermíone também adquire aquela que confronta gregos e bárbaros.

De tudo o que discutimos até o momento, concluímos que é fundamental refletir o gênero como uma categoria que põe em destaque os grupos femininos, permitindonos pensar a sociedade com homens e mulheres. Todas as formas de dominação são de interesse das relações de gênero, sejam elas entre homens e mulheres, livres e não livres; estando homens e mulheres presentes no interior dessas últimas duas categorias (CUCHET, 2018, p. 10 - grifo da autora). Acrescentamos a essas formas de dominação, aquelas entre gregos e não gregos.

\section{Gregos e não gregos: a barbárie no feminino}

Andrômaca é por definição bárbara, mas Eurípides a constrói sem carregar nos traços negativos da barbárie. Ao contrário, é Hermíone, a nobre grega, quem é descrita como capaz de cometer um duplo assassinato na ausência de seu marido, incluindo dentre as vítimas o único filho de Neoptólemo (RODRÍGUEZ CIDRE, 2010, p. 60-1). Este é um exemplo da tal relativização que Eurípides faz da dicotomia grego/bárbaro. A colocação de Elsa R. Cidre pode ser constatada a partir até mesmo de uma leitura descompromissada da peça, porém nos insere na segunda forma de relação de poder que nos propomos a considerar: aquela entre gregos versus bárbaros. Polarização essa considerada por Edith Hall (2004, p. 11) como um popular topos na tragédia.

O período de guerras marca a possibilidade daqueles que se julgavam superiores adotarem um comportamento de verdadeiros bárbaros. Assim, o termo bárbaro nomeou um comportamento selvático e animal a que todo o ser humano, em tempo de guerra, está sujeito (SILVA, 2005, p. 48). É o que de certa forma vemos, por exemplo, no comportamento da grega Hermíone. Mas vale ser destacado que antes do século 
V a.C. o termo bárbaro não tinha sido usado no plural, isto é, como um nome que denotava um mundo não grego (HALL, 2004, p. 9).

À Andrômaca fica claro que ela se encontra em uma terra estranha - xénas - na condição de cativa de guerra - dmoìs (vv.136-140). Ela, uma nobre troiana, agora vivendo sem liberdade na Hélade. Interessante é refletirmos sobre a posição, geográfica e cultural, de Troia na avaliação dos gregos. Ela ocupa um espaço meio fronteiriço entre o não ser grego e o ser grego, pois "embora asiática e estrangeira, a cidade de Príamo sempre gozou, dentro do critério grego, de um estatuto que tendeu a aproximá-la, em termos de estádio de progresso, da própria Hélade e a colocou na posição de um inimigo à altura" (SILVA, 2005, p. 44).

Os troianos não eram, para os helenos, bárbaros de mesmo patamar que os persas, por exemplo. Ou seja, Troia nunca foi vista sob o estigma de selvagem e/ou primitiva. Logo, Troia era bárbara apenas por não ser grega. Vidal-Naquet (2002, p. 37-8) menciona que tanto para Heródoto quanto para os poetas trágicos - Ésquilo, Sófocles e Eurípides -, os troianos são bárbaros, apesar de Eurípides se questionar acerca do valor desta relação de oposição. Em Homero, por exemplo, não encontramos claramente uma diferença marcante no que se refere à oposição gregos e bárbaros. O helenista (VIDAL-NAQUET, 2002, p. 39) faz uso de dois argumentos para defender essa proximidade entre gregos e troianos em Homero. O primeiro é a inexistência de problemas de comunicação entre as duas sociedades, isto é, não há alusão ao fato de falarem línguas diferentes. Emílio Crespo (2004/2005, p. 36) também ressalta tal similitude: "Os personagens falam a mesma língua". O segundo, o fato de Heitor não ter sido para a posterioridade o nome de um bárbaro. Quanto à questão de helenos e troianos falarem uma mesma língua, isso pode ser um recurso literário que atende ao público receptor dos poemas de Homero. Se autor e receptores são helenos, era comum que a língua utilizada na epopeia fosse aquela do domínio do emissor e de seu público.

Podemos vislumbrar em Troia uma arquitetura que a aproximava de uma pólis com suas muralhas, obra dos deuses (EURÍPIDES. Troianas, vv. 4-6, 814), um convívio social com valores semelhantes àqueles presentes nas comunidades tidas como civilizadas à época, como a xenia. Segundo Cuchet (2006, p. 57), a muralha troiana (alta, intransponível) pode ser concebida como metáfora do seu povo, oferecendo a eles um sentimento de invencibilidade que possivelmente era entendido como arrogância.

Para além da língua, Emilio Crespo (2004/2005, p. 36-7) enumera outras semelhanças entre helenos e troianos: veneram os mesmos deuses e oferecem os mesmos tipos de sacrifícios; alguns heróis gregos e troianos compartilham uma genealogia comum; vestimentas, costumes e armas são semelhantes; a organização cívica dos troianos parece mais complexa do que a dos gregos, mas isso pode se dar pelo fato de os helenos estarem em acampamento militar.

Apesar das semelhanças, a imagem dos troianos é construída a partir de diferenças com os gregos: os gregos atacam em silêncio, já os troianos ruidosamente; Aquiles enfatiza que eles oferecem cavalos vivos ao rio Escamandro; Príamo é polígamo; os troianos são arrogantes diante da vitória enquanto os gregos são prudentes; e, os 
gregos, diferentemente dos troianos nunca suplicam pela vida, abraçando os joelhos dos vencedores, quando capturados (CRESPO, 2004/2005, p. 36-7; MORAES, 2009, p. 65).

Porém o que melhor exprime o bárbaro é a sua condição de escravo, conforme Eurípides reforça na Andrômaca em uma das falas de Menelau (vv. 664-66): ${ }^{15}$ “... se minha filha [Hermíone] não der à luz e desta nascerem filhos, sobre a terra da Ftia I serão eles soberanos e, bárbaros pelo nascimento, vão governar os gregos?!”.

Não obstante o seu comportamento de excessos que seria mais condizente com os bárbaros do que com os helenos, Hermíone caracteriza a raça bárbara como aquela em que pai une-se à filha, filho à mãe, irmã ao irmão e os parentes matam-se uns aos outros, não havendo leis que impeçam tais costumes (vv. 174-76). Esta caracterização feita pela personagem, além de reiterar a desvalorização do bárbaro ante o heleno, nos remete ainda ao narrado por Heródoto (3. 31) acerca de Cambises que teria se unido à sua própria irmã. Aqui os persas são recuperados como alteridade máxima dos gregos. A ausência de leis e de uma sociedade organizada remete a uma situação de barbárie frente à complexidade políade. Na vida civilizada em pólis, segundo ainda Hermíone, não é decente que um só homem coabite com duas mulheres (vv. 177-80). Destaca-se que a pólis é elemento fundamental para a construção do sentido de ser grego.

Segundo Renata Cardoso de Sousa (2019, p. 159), "embora Hermione frise o discurso helênico acerca do bárbaro, ela mesma é mostrada no limiar entre os dois grupos étnicos, justamente porque o espartano é, cada vez mais, visto como um Outro", principalmente no contexto da Guerra do Peloponeso. De forma semelhante, Andrômaca e os troianos têm o seu estatuto de bárbaro reforçado; ele é ratificado, isto porque, ainda na interpretação de Renata C. de Sousa, "a tragédia euripidiana reforça as fronteiras étnicas entre os bárbaros para, ela mesma, aproximar aqueles que estão contra os atenienses a eles".

Para Edith Hall (2004, p. 1, 2 e 11), quando os gregos escreveram sobre os bárbaros - que são vistos como seus opostos -, eles estavam experimentando um exercício de autodefinição. A helenista enfatiza que tal invenção teria sido forjada a partir das Guerras Greco-Pérsicas (490-479 a.C.) ${ }^{16}$. Mas como as peças de Eurípides são marcadas pela atualidade e a realidade atual do poeta é a da Guerra do Peloponeso ${ }^{17}$, essa invenção do bárbaro ganha novas matizes.

Com os conflitos entre atenienses e espartanos e seus respectivos aliados, "a apreciação etnográfica e a esquematização que transforam os não-gregos, tornados os bárbaros ou o bárbaro, em puro instrumento crítico em um discurso dos gregos sobre os gregos" (PESCHANSKI, 1993, p. 58). A partir desse momento temos o discurso, no qual as tragédias de Eurípides se inserem, que transforma os não-atenienses em bárbaros. O bárbaro agora é o próprio grego, o que permite ao poeta construir Hermíone, uma espartana, com traços barbarizados, conforme vimos anteriormente. Assim como Jonathan Hall (2000, p. 33), também compreendemos a etnicidade como um fenômeno relacional, isto é, constituído a partir do contato com os Outros e é a 
partir desse contato que ela também se define e se mantém. E esses Outros, no caso de Eurípides, são os gregos não-atenienses.

No seu embate com Hermíone, o que sobressai é o fato de Andrômaca, apesar de estrangeira e supostamente bárbara, se mostrar mais grega nas atitudes, na sua moderação e na sua virtude, do que a princesa espartana. Esta opta pela violência desmedida e por toda a espécie de excessos que eram entendidos pelos gregos como esperados de um bárbaro. Os gregos barbarizados de Eurípides invertem a tese aceita de que os helenos são superiores ao resto do mundo, um cânon tantas vezes sublinhado pelos poetas trágicos nas suas celebrações dramáticas de uma identidade coletiva grega (HALL, 2004, p. 222-23).

O que percebemos na Andrômaca é a guerra atuando no sentido de criar uma nova ordem sem fronteiras na qual predomina a ideia do grego/barbarizado e do bárbaro/civilizado. A noção da barbárie no Outro dá lugar à barbárie no próprio grego, afinal são os helenos matando e escravizando helenos. Algo que para a ideologia da comunidade política seria uma anomalia.

\section{Conclusão}

Andrômaca, assim como outras tragédias de Eurípides, coloca em relevo um dos traços característicos do poeta: a concessão de espaço de ação às personagens femininas. Por mais que Hermíone dependesse de seu pai, Menelau, para concretizar o seu plano de assassinar Andrômaca e o filho e que a viúva de Heitor tenha sido salva por Peleu, os personagens masculinos não são aqueles responsáveis pelo desenvolvimento da narrativa na peça. As ações determinantes são femininas.

Complexa é a composição da personagem Andrômaca. Ela é bárbara - porque é cativa troiana -, mas possui um comportamento mais esperado de uma esposa ideal grega. E acima de tudo, ela é capaz de discorrer em defesa do casamento grego:

\footnotetext{
Não é pelos meus fármacos que teu marido te odeia, mas por não seres dotada para viver em comum. Filtro também é o seguinte: não é a beleza, mulher, mas as virtudes que alegram os companheiros do leito. (...) Deve a mulher, ainda que dada a alguém de baixa condição, amar o marido e não ter com ele discussões sobre nobreza (vv. 205-14).
}

Sob o filtro de Eurípides, Andrômaca, mesmo quando isso parecia completamente improvável, assume a defesa de ideais que não seriam do seu universo cultural. Neste aspecto nos encontramos diante de um contraste com Hermíone que mais se assemelha, em atitudes, àquilo que culturalmente se esperava de um bárbaro. Tal contraste vem ao encontro do que Barbara Cassin e Nicole Loraux (1993, p. 10) defendem ao afirmar que "é-se grego por cultura e não por natureza". Logo, qualquer grego pode então barbarizar, independente de natureza, solo ou sangue. E a literatura - aqui expressa na tragédia euridipiana - permanece como um espaço essencial de expressão das diferenças (TEZZA, 2018, p. 22). 
Concubinato e esterilidade constituem dois temas relevantes na Andrômaca. Esses temas aliados marcam a possibilidade da presença dos Outros - Menelau, Peleu, Orestes - no grupo doméstico do ausente Neoptólemo, e enfatiza a alteridade de Andrômaca como concubina, escrava e bárbara, assim como a de Hermíone como esposa legítima. Alteridades essas que são permeáveis, de acordo com os comportamentos assumidos pelas personagens: o da bárbara que defende a cultura grega e o da grega que age como bárbara.

Assim sendo, podemos enfatizar que Andrômaca se encontra próxima do contexto da domesticidade mais comum, mais próxima daquilo que o público identificava como sendo o ideal de esposa ateniense, apesar de não a ser. Andrômaca é o inesperado: é a outra como escrava e bárbara, é subversiva e ameaçadora como toda mulher, mas mantém domesticada a sua natureza.

\section{Referências}

BAILLY, A. Dictionnaire Grec-Français. Paris: Hachette, 2000.

CASSIN, B.; LORAUX, N. Prefácio. In: CASSIN, B.; LORAUX, N.; PESCHANSKI, C. (Org.). Gregos, bárbaros, estrangeiros: a cidade e seus outros. Rio de Janeiro: Ed. 34, 1993, p. 7-10.

CHANTRAINE, P. Dictionaire Étymologique de la Langue Grècque - Histoire des Mots. Paris: E. Klincksieck, 1983.

CHONG-GOSSARD, J.H.K. Andromache. In: LAURIOLA, R.; DEMETRIOU, K.N. (ed.). Brill's Companion to the Reception of Euripides. Leiden: Boston, Brill, 2015, p. 143-73.

CRESPO, E. Los nombres de persona de los troyanos y de los griegos en la llíada. Clássica, v. 17/18, p. 33-47, 2004/2005.

CUCHET, V.S. Gender Studies et domination masculine: Les citoyennes de l'Athenes classique, un defi pour l'historien des institutions. HAL: archives-ouvertes.fr. p. 1-22, 2018 (consultado em abril de 2019).

CUCHET, V.S. Quais direitos políticos para as cidadãs da Atenas clássica?. Hélade, v. 4, n०. 1, p. 143-158, 2018.

CUCHET, V.S. O que o Gênero faz na Antiguidade grega (séculos V e IV a.C.). In: LIMA, A.C.C. (Org.). Imagem, Gênero e Espaço: representações da Antiguidade. Niterói: Alternativa, 2014, p. 53-70.

CUCHET, V. S. Libérez la patrie! Patriotisme et politique em Grèce ancienne. Paris: Belin 2006.

DESERTO, J. Andrômaca: uma outra forma de poder. In: LOPES, M.J.F et alli (Org.). Narrativas do Poder Feminino. Braga: Universidade Católica Portuguesa, 2012, p. 91-100.

DI BENEDETTO, V. Euripide: teatro e società. Torino: Einaudi, 1971. 
EURÍPIDES. Andrômaca. Trad. José Ribeiro Ferreira. In: SILVA, M.F.S. (Coord.) (2010), Eurípides: Tragédias II. Lisboa, Imprensa Nacional-Casa da Moeda.

EURÍPIDES (2004), Duas tragédias gregas: Hécuba e Troianas / Eurípides. Tradução Christian Werner. São Paulo, Martins Fontes.

FEITOSA, L.; RAGO, M. Somos tão antigos quanto modernos? Sexualidade e Gênero na Antiguidade e na Modernidade. In: RAGO, M.; FUNARI, P. P. A. (org.) Subjetividades antigas e modernas. São Paulo: Annablume, 2008, p. 107-21.

FOXHALL, L. Studying Gender in Classical Antiquity. Cambridge: Cambridge University Press, 2013.

GAMBON, L. La institucion imaginaria del oikos en la tragedia de Euripides. Bahia Blanca: Editorial de la Universidad Nacional del Sur, 2009.

GILHULY, K. The Feminine Matrix of Sex and Gender in Classical Athens. New York: Cambridge University Press, 2009.

GURINA, M.P. Alguien se acordará de nosotras: Mujeres en la ciudad griega antigua. Barcelona: Bellaterra, 2008.

HALL, E. Inventing the Barbarian: Greek self-definition through tragedy. Oxford: Oxford University Press, 2004.

HALL, J.M. Ethnic identity in Greek Antiquity. Cambridge: Cambridge University Press, 2000.

HARTOG, F. O espelho de Heródoto. Ensaio sobre a representação do outro. Belo Horizonte: UFMG, 1999.

HERÓDOTO (2010), Histórias - Livro III. Trad. Maria de Fátima Silva e Cristina Abranches. Lisboa, Edições 70.

HOMERO (2013), Ilíada. Trad. F. Lourenço. São Paulo, Cia. das Letras.

JUST, R. Women in Athenian Law and Life. New York: Routledge, 1994.

KEULS, E.C. The Reign of the Phallus: Sexual Politics in Ancient Athens. Califórnia: University of California Press, 1993.

LESKY, A. História da Literatura Grega. Lisboa: Fundação Calouste Gulenkian, 1995.

LIDDELL and SCOTT'S. An Intermediate Greek-English Lexicon. Oxford: At the Clarendon Press, 1992. 
LESSA, F.S. Etnicidade e poesia trágica: O Ciclope de Eurípides. In: SILVA, M.F.; FIALHO, M.C.; BRANDÃO, J.L. (Coords.). O Livro do Tempo: Escritas e reescritas - Teatro GrecoLatino e sua recepção I. Coimbra: Imprensa da Universidade de Coimbra, 2016, p. 47-58.

MATOS, M.I.S. História, Mulher e Poder: Da invisibilidade ao gênero. In: SILVA, G.V.; NADER, M.B.; FRANCO, S.P. (org.). História, Mulher e Poder. Vitória: Edufes, 2006, p. 9-23.

MORAES, A.S. Os sentidos da itinerância dos aedos gregos. Phoînix, Rio de Janeiro, v. 15, p. $62-73,2009$.

PESCHANSKI, C. Os bárbaros em confronto com o tempo (Heródoto, Tucídides, Xenofonte. In: CASSIN, B.; LORAUX, N.; PESCHANSKI, C. (Org.). Gregos, bárbaros, estrangeiros: a cidade e seus outros. Rio de Janeiro: Ed. 34, 1993, p. 56-74.

POMEROY, S. Diosas, rameras, esposas y esclavas: Mujeres en la Antigüedad clásica. Madrid: Akal, 1999.

POUTIGNAT, Ph.; STREIFF-FENART, J. Teorias da etnicidade. Seguido de Grupos étnicos e suas fronteiras de Fredrik Barth. São Paulo: Ed. UNESP, 1998, p. 141-72.

RODRÍGUEZ CIDRE, E. Cautivas Touyanas: El mundo femenino fragmentado en las tragédias de Eurípides. Córdoba: Ediciones del Copista, 2010.

SCHMITT PANTEL, P. A História das Mulheres na História da Antiguidade, Hoje. In: DUBY, G.; PERROT, M. (org.) História das Mulheres no Ocidente. Porto: Afrontamento, v. I, 1990, p. 591-603.

SCODEL, R. The captive's dilemma: sexual acquiescence in Euripides' Hecuba and Troades". HSPh 98, Harvard, p. 137-54, 1998.

SCOTT, J. Prefácio a Gender and Politics of History. Cadernos Pagu: desacordos, desamores e diferenças 3, Campinas, 1994.

SCOTT, J. Gênero: uma categoria útil de análise histórica. Educação \& Realidade 20, Porto Alegre, p. 71-99, 1995.

SILVA, M.F.S. Madre de Guerra. Eurípides, Andrómaca y Troyanas. In: MARTINO, F.; MORENILLA, C. Palabras sabias de mujeres. Bari: Levante Editori, 2013, p. 361-76.

SILVA, M.F.S. Ensaios sobre Eurípides. Lisboa: Cotovia, 2005.

SOUSA, R. C. Construindo Identidades: comparação dos discursos étnicos helênicos entre a epopeia e a tragédia (séculos VIII e V a.C.). 2019. Tese (Doutorado em História Comparada) - Instituto de História da Universidade Federal do Rio de Janeiro, Rio de Janeiro, 2019.

TEZZA, C. Literatura à margem. Porto Alegre: Dublinense, 2018. 
TUCÍDIDES. História da Guerra do Peloponeso. Trad. Raul M. Rosado Fernandes e M. Gabriela P. Granwehr. Lisboa: Fundação Calouste Gulbenkian, 2010.

VERNANT, J-P.; VIDAL-NAQUET, P. Mito e Tragédia na Grécia Antiga. São Paulo: Perspectiva, 1999.

VIDAL-NAQUET, P. O mundo de Homero. São Paulo: Cia. das Letras, 2002.

VIDAL-NAQUET, P. The place and status of foreigners in Athenian tragedy. In: PELLING, C.B.R. (Ed.). Greek Tragedy and the Historian. Oxford and New York: Clarendon Press/ Oxford University Press, 1997, p. 109-119.

\section{Notas}

${ }^{1}$ Muitos helenistas defendem que a peça Andrômaca, de Eurípides, não possua uma unidade (PHILLIPPO, 1995, p. 355).

2 Ver: GILHULY (2009); SCHMITT PANTEL (1990, p. 591-603); MATOS (2006, p. 9-23).

${ }^{3}$ Além de relacional e historicamente construído, o gênero é plural; isto porque, "existem muitos 'femininos' e 'masculinos', e esforços vêm sendo feitos no sentido de se reconhecer diferenças dentro da diferença, apontando que mulher e homem não constituem simples aglomerados: ..." (MATOS, 2006, p. 13).

${ }^{4}$ Dentre os diversos fatores neste quadro de oposições entre gregos e bárbaros, temos a língua a marcar a diferença e a distância: “... no critério helênico, o bárbaro, ao mesmo tempo que articula sons que obedecem a uma cadeia incompreensível, realiza um processo mental que o distingue do grego" - SILVA (2005, p. 15). Ver também: HALL (2004, p. 3-4).

5 Tradução de Frederico Lourenço (2013).

6 Segundo P. Vidal-Naquet (2002, p. 79), "impossível não ligar o seu nome ao que se pode chamar de supermasculinidade do seu círculo", isto devido ao fato de ela possuir sete irmãos e viver em um universo masculinizado. Seus irmãos, além do próprio pai, teriam sido mortos por Aquiles (cf. Ilíada. 6. 413-24).

${ }^{7}$ Certamente Andrômaca se vê como fraca por sua condição de escrava, mulher e concubina.

8 Todas as citações da tragédia Andrômaca foram traduzidas por José Ribeiro Ferreira (2010).

${ }^{9}$ Quanto a esta questão, ver: RODRÍGUEZ CIDRE, 2010, p. 63-64.

10 Podemos também pensar, a título de exemplo, na relação Fedra e Hipólito, além de Jocasta e Édipo.

11 "Pois diz que, por meio de drogas secretas, a torno estéril e odiada ao marido e que desejo habitar esta casa, em sua vez, expulsando-a à força do seu tálamo" (vv. 33-35).

${ }^{12} \mathrm{~A}$ partir desta lei atribuída a Péricles, somente seriam cidadãos os filhos de pai e mãe atenienses.

13 Consultar também os versos 248, 595-601, 601-10, 631, 680-85. Em Hécuba a situação se repete nos versos 265-70, 441-43 e 943-51.

${ }^{14}$ Num diálogo entre Andrômaca e a Escrava, Eurípides não deixa de mencionar os artifícios femininos para as saídas de casa (vv. 84-85). 
15 Sobre essa questão, cf. Helena, v 276, Troianas, v. 933, Ifigênia em Áulide, vv. 1400-401.

16 Jonathan M. Hall (2000, p. 44) também é partidário de que o conceito de bárbaro tem por referencial as Guerras Greco-Pérsicas. Consultar também: PESCHANSKI, 1993, p. 56. Já François Hartog (1999), defende que as Guerras Greco-Pérsicas não foram o marco dessa diferenciação, visto que ela já ocorria antes.

17 "E as peças de Eurípides estão marcadas pela atualidade, seja pela guerra (a do Peloponeso), seja pelas ideias sofísticas, predominando a presença concreta do sofrimento humano, venha ele da paixão, da guerra, do erro ou dos deuses" (LESSA, 2016, p. 48).

Fábio de Souza Lessa é professor Doutor - ORCID: https://orcid.org/0000-0002-4829-6651. Laboratório de História Antiga (LHIA) do Instituto de História (IH) e dos Programas de Pós-Graduação em História Comparada (PPGHC) e de Letras Clássicas (PPGLC) da Universidade Federal do Rio de Janeiro (UFRJ). Bolsista de Produtividade em Pesquisa do CNPq. E-mail: fslessa@uol.com.br. 